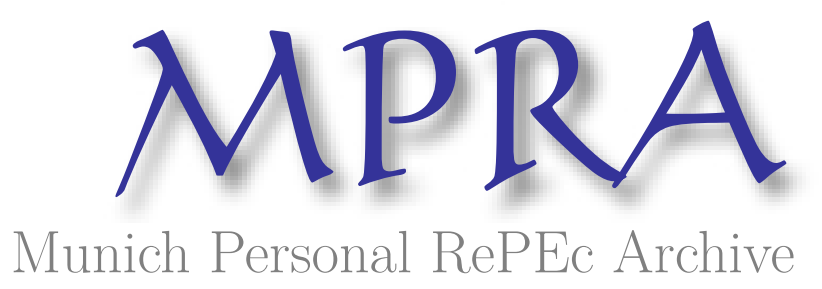

\title{
Equitable and Sustainable Development of Foreign Land Acquisitions: Lessons, Policies and Implications
}

Asongu, Simplice and NGUENA, Christian L.

January 2014

Online at https://mpra.ub.uni-muenchen.de/66598/

MPRA Paper No. 66598, posted 13 Sep 2015 08:43 UTC 


\section{AFRICAN GOVERNANCE AND DEVELOPMENT INSTITUTE}

\section{A G D I Working Paper}

\section{$\mathrm{WP} / 14 / 038$}

\section{Equitable and Sustainable Development of Foreign Land Acquisitions: Lessons, Policies and Implications}

Published in: Handbook of Research on In-country Determinants and Implications with Foreign Land Acquisitions, First edited by E. Osabuohien, 12/2014: chapter Chapter 1: pages 1-20; IGI Global.

\section{Simplice A. Asongu}

African Governance and Development Institute,

Yaoundé, Cameroon.

E-mail: asongusimplice@yahoo.com

\section{Christian L. Nguena}

Association of African Young Economists (AAYE),

University of Yaoundé II, Cameroon

Yaoundé, Cameroon. 


\title{
AGDI Working Paper
}

Research Department

\section{Equitable and Sustainable Development of Foreign Land Acquisitions: Lessons, Policies and Implications}

\author{
Simplice A. ASONGU ${ }^{1 *}$ and Christian L. NGUENA ${ }^{2 *}$
}

December 2014

\begin{abstract}
Large-scale agricultural land acquisitions have been covered substantially in recent literature. Despite the wealth of theoretical and empirical studies on this subject, there is no study that has reviewed existing literature in light of concerns over sustainable and equitable management. This chapter fills the gap by analyzing and synthesizing available literature to put some structure on existing knowledge. The paper has a threefold contribution to the literature. First, it takes stock of what we know so far about the determinants of land grab. Second, it presents a picture of sustainable and equitable development of the foreign land acquisitions. Third, policy syndromes are examined and policy implications discussed. Based on the accounts, the issues are not about whether agricultural investments are needed, but on how they can be sustainably and equitably managed to make positive contributions to food security and domestic development.
\end{abstract}

Keywords: Governance; Equity; Sustainable Development; Land Grab

\section{INTRODUCTION}

Long-run lease and/or purchase of agricultural land in developing countries by private or public foreign investors has been subject to much research focus during the past decade (UN, 2010; Arezki et al., 2011; Olanya, 2012; Cuervo-Cazurra, 2006; Cotula et al., 2009; Cotula, 2013; Osabuohien, 2014). Countries on target for the most part are those with water and arable resources in Latin America, South \& Central Asia and Africa. Australia, Ukraine and Russia are also offering foreign investors large tracts of farmland. These foreign investors include: on the one hand, a private sector in Europe consisting of investment banks and hedge funds; and on the other hand, public and private investors from Asia (UN, 2010). While foreign-owned plantations have existed in many parts of the world since the colonial era, the recent rush (after a sharp decline in the 1980s) is a new investment strategy that is strongly motivated by energy, food and water security.

Many reasons have also been documented for the interest of analyzing large-scale land deals as an important development concern. Consistent with Arezki et al. (2011), one of such concerns is the debate over the structure of agricultural production. According to the narrative, economists have emphasized the relevance of a smallholder poverty reduction structure because majority of the poor are still based in local areas (World Bank, 2007; Lipton, 2009). In essence, the rapid poverty mitigation in Asian countries has been accompanied by an exceptionally substantial poverty elasticity of prosperity in agriculture of small scale (Loayza \& Raddatz 2010; De Janvry \& Sadoulet, 2010). On

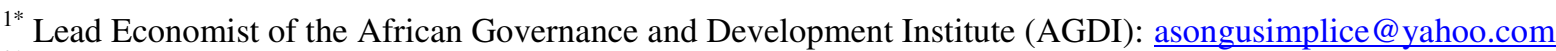

2* Association of African Young Economist (AAYE), CEO and Co-founder; [Contact: nguena@aaye.org].
} 
the other hand, despite the soaring inflation (Asongu, 2013a, 2014a; Nguena, 2013ab; Tsafack \& Nguena, 2014ab) with the limited success by smallholders in sub-Saharan Africa to improve productivity (Collier, 2008) and seemingly export competitiveness of large farms in Eastern Europe and/or Latin America during the 2007/2008 world food crisis, many questions have been raised about whether agriculture of large scale can be the blueprint to poverty alleviation and development (Arezki et al., 2011).

Irrespective of the scenario considered above, it remains an economic fact that the polemics and politics surrounding land grab are raising interesting concerns about whether there is enough transparency and competition in foreign land acquisition (FLA). In other words, there are issues on whether, contrary to having their land taken without their consent; land owners are transferring their land to foreign investors at fair prices. These lines of thought are consistent with development literature suggesting that institutional quality is a necessary condition for resource management (Boyce \& Ndikumana, 1998, 2001; Fosu, 2013ab; Asongu, 2012). Essentially, resource booms in developing countries are associated with substantial rent-seeking and corruption (Garoupa \& Jellal, 2007; Jellal \& Bouzahzah, 2013; Asongu, 2014b) which do not lead to equitable and sustainable management of resources.

Inclusive and sustainable developments have substantially been the focus of a recent stream of development studies in general (Ingwe et al., 2010; Nyarko, 2013; Anyanwu, 2013; Anyanwu \& Augustine, 2013) and FLA works in particular (Olanya, 2012; Hathie \& Yiyugsah, 2013). Accordingly, issues of equity and sustainability are intrinsically linked to the securities in food, energy and water that are driving this new investment strategy across the globe. The more preoccupying fact is that the current streams of land lease and purchase arrangements consist mainly of shifting water and land uses to long-distance farming from essentially local farming, for food and energy needs. Consistent with the UN (2010), the soaring scale of this phenomenon, combined with growing environmental and economic issues motivating the growth have created a new dynamic of global importance. According to the narrative, in addition to crops, water and land are also being commodified and commercialized in the global market of land and water. The same account holds that the proposed investments for the most part often have little or nothing in common with the country's domestic agricultural development plans. The risk of these developments is that water users, food needs and land owners are displaced.

In light of the above, there have been growing concerns about the sustainable and equitable development of these FLAs (Ingwe et al., 2010). While the former is motivated by increasing deforestation, green house emissions and climate change, the latter draws from how such land acquisition practices affect income distribution in the short- and long-terms (Liu, 2013; Wouterse et al., 2011; Osabuohien, 2014). These concerns are relatively more acute in Africa (Robertson \& Pinstrup-Andersen, 2010; German et al., 2011; AGRODEP, 2013). Large-scale agricultural land acquisitions in African countries have been covered substantially in recent literature. Despite the wealth of theoretical and empirical studies on this subject, as far as we have reviewed there is no study that has analyzed existing literature in light of concerns over sustainable management. This position is consistent with Starr (2013) who has recently established that the literature on 'land grabbing' remains considerably biased and does not fully appreciate the full diversity of land investments. This present chapter fills this gap by reviewing existing literature to put some structure on the equitable and sustainable development trends of the phenomenon.

This chapter has a threefold contribution to existing literature. First, it takes stock of what we know so far about the determinants of land grab. Second, it presents a picture of sustainable and equitable development of FLAs. Third, policy syndromes are examined and policy implications discussed.

The rest of the chapter is organized as follows. Section 2 reviews the relevant literature on the determinants of FLA essential for a good understanding of equity and sustainability of FLAs. Section 3 discusses equity and sustainability in land grab, with particular emphasis on: food security and sovereignty; water and energy security; environmental protection; socio-economic protection and unbalanced geopolitical power. Policy syndromes and implications discussed in Section 4 are related 
to peasant rights, water and energy issues, food security, environmental and labor laws, transparency and development, and employment opportunities. Section 5 concludes.

\section{DETERMINANTS OF FDI AND/OR FLA}

Understanding the determinants of foreign direct investment (FDI) and/or foreign land acquisition (FLA) is necessary for a critical analysis of equity and sustainability of land grab in developing countries (Tsafack \& Nguena, 2014c). This is essentially because the Zambian experience has shown that the African continent is in dire need of other forms of investments after the failed FDIintended privatization policies (Rolfe \& Woodward, 2004). Consistent with Akpan (2014), the determinants of FDI vary with a plethora of factors, inter alia; measurement of variables, estimation techniques, data span and contexts of studies (Asiedu, 2002; Moosa, 2002; Moosa \& Cardak, 2006; Asiedu, 2006; Sekkat \& Veganzones-Varoudakis, 2007; Ranjan \& Agrawal, 2011; Buchanan et al., 2012; Hajzler, 2014). To the best of our knowledge, determinants of FDI/FLA in developing countries can be classified in six main strands: quality of business climate (return, infrastructure, institutions, trade openness...etc), weak land governance, tenure security of current users, resource-seeking, global economic shocks and regional factors. While the first strand of determinants is focused on FDI, the last-five are more specific to the FLA feature of FDI.

In the first strand on business climate, using 1400 firms in 19 sub-Saharan Africa countries, Amendolagine et al. (2013) have assessed the drivers of backward relationships of FDI and established that substantial local nexuses are linked with time, market factors and local partners. Factors of return on capital and infrastructure have been documented by Asiedu (2002) in the same sub-region. The role of trade openness, market size and infrastructure availability (Büthe \& Milner, 2008; Kinda, 2010; Vijayakumar et al., 2010; Bartels et al, 2009; Darley, 2012; Jadhav, 2012; Anyanwu, 2012; Akpan et al., 2014; Bartels et al., 2014), labor costs and incentive packages (Tuomi, 2011; Vijayakumar et al., 2010; Bartels et al., 2014) have also been confirmed. At the institutional level, the absence of corruption (Wei, 2000; De Maria, 2010), democracy (Asiedu \& Lien, 2011), low political risk (Busse \& Hefeker, 2007), general quality of domestic institutions (Gastanaga et al., 1998; Asongu, 2012; Neumayer \& Spess, 2005; Kinda, 2010; Tuomi, 2011; Cleeve, 2012; Abdioglu et al., 2013; Hayakawa et al., 2013; Bartels et al., 2014) and, regulatory quality \& government effectiveness (Jadhav \& Katti, 2012).

Contrary to mainstream literature on foreign investment, Areski et al. (2011) have not confirmed the quality of business climate as a motivation for FLA. Hence in the second strand on weak land governance, we find a plethora of studies that have documented weak quality of institutions to either have a positive or insignificant effect on FLA. Kolstad \& Wiig (2011) have investigated the drivers of Chinese FDI in Africa and established that weak governance is the primary factor motivating their investments. Asongu \& Aminkeng (2013) in debunking myths surrounding ChinaAfrica relations have established that Western companies are also making a lot of business in Africa with governments of questionable institutional and democratic standards. This position has been later confirmed by Akpan et al. (2014) who have found corruption not to significantly deter FDI in the BRICS and MINT countries. BRICS stands for 'Brazil, Russia, India, China \& South Africa' while MINT represents 'Mexico, Indonesia, Nigeria \& Turkey'.

The third strand concerns tenure security issues that have also been documented to determine the location of FLA decisions. The thesis has been confirmed by the UN (2010) as well as by Arezki et al. (2011) in terms of land rights security. Land tenure system has a substantial effect on food security and sustainable development in Africa (Economic Commission for Africa, 2004). Borrowing from Okoth-Ogendo (2008), Ingwe et al. (2010) has identified one of the problems of FLA as: taken away the land of peasants which are possessed on communal tenure systems that starkly contrast with official land titles related to 'indigenous colonialist' controlled neoliberal capitalist systems, who have used various forms of manipulation in the past to alienate Africans from their land. A position that is broadly consistent with Wouterse et al. (2011). German et al. (2011) interestingly document this tenure issue from the perspective of customary rights. The authors use policy interviews and documents from varying discussions and sectors which affected communities and customary leaders, 
to provide an in-depth comparative analysis of institutional and legal frameworks as well as actual practices linked with the FLA in Mozambique, Ghana, Zambia \& Tanzania. They conclude that despite their wide recognition, customary rights are not very well protected in FLA negotiations. Thaler (2013) has postulated that these acquisitions target nations with poor land tenure security that are always characterized by corrupt, authoritarian or weak governments. Liu (2013) concludes that in countries where governance is weak and local land rights are not clearly spelt-out, FLA raises a number of important risks for the local population. Osabuohien (2014) has recently shown that local institutions do not have a substantial influence on FLA decisions because they are overwhelmed by the State.

In the fourth strand, resource-seeking ambitions have been established as the main motives for FLA/FDI (UN, 2010; Kolstad \& Wiig, 2011; Jadhav, 2012; Jadhav \& Katti, 2012; Rogmans \& Ebbers, 2013; Aleksynska \& Havrylchyk, 2013; Lay \& Nolte, 2014). Asongu \& Aminkeng (2013) have debunked the Kolstad \& Wiig (2011) position on resource-thirty China by stating that most FDI decisions in the African continent are motivated by resource interest, be it from Chinese or Western investors. While Jadhav (2012) has concluded that the availability of natural resources has a negative incidence on FDI especially if highly endowed countries limit potential resource-seeking FDI with protectionist policies (Rogmans \& Ebbers, 2013), mainstream literature has consistently established resource grabbing as the principal motivation for FLA acquisition (UN, 2010; Arezki et al., 2013). As a direct extension of Arezki et al. (2013), Lay \& Nolte (2014) have confirmed the resource-seeking strategy as the main determinant of investments that are land-based. Consistent with the UN (2010), some of the reasons advanced are depleting fresh water reserves (in the case of Saudi Arabia), need of biofuels (reference to US farm corporations) and soaring global food crises.

The fifth strand consists of a stream of studies that has documented global shocks like financial and food crises as the main drivers of foreign land purchases for the purpose of agriculture (Wouterse et al., 2011). Consistent with the UN (2010), the most apparent driver of these purchases was the food crisis of 2008. According to the narrative, countries that substantially depend on the importation of food were disappointed by the exporting nations' decisions to impose restrictions on critical food crops. With up-to 25 nations imposing export restrictions or bands in that year (including Argentina, India, Russia \& Vietnam), private sectors and financial investors saw other opportunities in investment and speculation (Clapp, 2013; Fairbairn, 2013; Isakson, 2013). It is in this light that many investment banks set up agricultural funds of investment (including, Black Rock and Goldman Sachs in the USA, Knight Frank in the UK and Deutsche Bank in Germany). In summary, the burgeoning growth of emerging countries, increasing appeals in biofuels as a substitute to fossil fuels and recent variations in food prices have sped-up the scale and pace of FLA in poorer countries (German et al., 2011)

In the sixth strand, regional factors have also been projected to determine FLA decisions. Asiedu (2002) prior to the 2007/2008 financial/food crisis concluded Africa was different when it came to FDI by postulating that the sub-Saharan Africa (SSA) had an important 'adverse effect" as she received less FDI by virtue of her geographical location. From an exclusively African perspective, Anyanwu (2012) does not confirm Asiedu's position. According to the author, Southern and Eastern African sub-regions are positively disposed for more inward FDI. Many authors are today presenting a thesis that SSA is the principal targeted for FLA because of low usage of water supplies (barely $2 \%$ according to the UN, 2010). There are well established North-South relations when it comes to FDI (Aleksynska \& Havrylchyk, 2013). While existing local partners (Amendolagine et al., 2013) are already a very determining factor owing to strong colonial ties, China's strategy on non-interference and partnership (complementarity and soft power) is paying-off because it completely cuts adrift policies of former colonial powers (Yin \& Vaschetto, 2011).

\section{Equitable and Sustainable Development of Foreign Land Acquisitions (FLAs)}

To the best of authors' knowledge, mainstream literature is consistent with the thesis that ensuring sustainable and equitable development in FLA will require amongst others tackling issues of: food security, water insecurity and, environmental and social protection. These issues are most relevant when two questions are integrated into the problem statement. How much land is at stake and 
for which period of time (UN, 2010). According to the narrative, a quantitative inventory in many African countries (notably, Ghana, Ethiopia, Mali, Madagascar \& Sudan) gathered by the International Institute for Environment and Development (IIED), the International Fund for Agriculture and Development (IFAD) and the Food and Agricultural Organization (FAO) suggest that between 2004 and 2009, a total of 2, 492, 684 hectares of land had been approved and acquired. In comparative terms, this area represents about $50 \%$ of the arable land in the UK and thrice the size of that in Norway. Notable cases include: a 150, 000 hectares in Ethiopia for a livestock project and 452, 500 hectares in Madagascar for biofuel. On a more general note, FLA has for the most part involved hectares in excess of 10, 000 and periods of lease between 50-99 years. Over the past two years, sovereign wealth funds and States have joined the main actors: agribusinesses, hedge funds, commodity traders and investment banks. Some deals are up to 1,000, 000 hectares. The 'King Abdullah initiative for Saudi agricultural investment abroad' is a scheme by Saudi Arabia that provides credit facilities to Saudis investing in agriculture abroad. Accordingly, 60\% of funding for the investment by 'Hail Agricultural Development Corporation (HADCO)' in Sudan has been provided by the Saudi government. In the same vein, in collaboration with United Arab Emirates (UAE), Abraaj Capital (a private equity) has acquired farmland of about 800, 000 hectare in Pakistan. Tax incentives are provided for FLA and land is sometimes exchanged for investment in infrastructural projects.

\section{Food Security or Sovereignty}

It is now an economic fact that international agricultural trade in commodities is key to the livelihoods of a substantial number of famers in the world as well as most food security strategies of countries. However, current trade policies are undermining livelihoods because they are contributing to food insecurity. Food sovereignty (FS) came-up as part of a mobilization effort to resist the World Trade Organization's (WTO) Agreement on Agriculture and its imposition to domestic agricultural policy of multilateral disciplines (Burnett \& Murphy, 2013).

Consistent with Bizikova et al. (2013), there are certain elements that are essential in understanding the concept of food security: food availability (affected by production, distribution \& exchange); food accessibility (entailing preference, affordability \& allocation); food utilization (safety, social \& nutritional values) and; the stability of food over time. Burnett \& Murphy (2013) have argued that trade is crucial in sustaining the livelihoods of small-scale producers who are already very active in the FS movement. Still, according to their narrative, trade which is strategically important is not explored in discourses on FS. Consistent with Starr (2013), in spite of the growing interest in FLA, the literature has remained biased in a plethora of ways and has failed to appreciate the full diversity of investment in land registered over the last decade. The paper has identified and analyzed three dark spots in comparative land grab literature, notably: the non-incorporation of investment that are not productive like speculation; contrary to capital flows, the misguided orientation towards investor nationality and; the tendency not to account for how 'terms of land deal' are shaped by domestic actors. The paper contributes to the literature by mapping the complex interactions among investors and a plethora of domestic actors, amongst others: civil society organizations and government.

For organizational purposes, the literature on this strand can be substantially discussed in four main strands: financialisation of food (Clapp, 2013; Fairbairn, 2013; Isakson, 2013), food shortages (Mbunda, 2013; Fernández et al., 2013; Berstein, 2013), a synthesis (Olanya, 2012; Van der Ploeg, 2013) and contrasts (UN, 2010).

The first strand entails a thorny issue of financialization because agricultural land is now a form of portfolio investment in capital markets (Fairbairn, 2013). According to the narrative, a substantial number of new investments involve both land ownership and agricultural production. In essence, farmland is in tune with financial discourses because it emphasizes some kind of exposure to 'value investing' and long-run trends. With land currently as a financial asset, speculative profits, hedging inflation and capital gains are core to investment in farmlands.

Clapp (2013) has provided a new perspective on how strengthened financialisation of the world food system has influence politics. The author's contribution puts forward two interrelated 
arguments. First, due to financialisation a novel type of distancing has surfaced which has: increased the number of actors involved and abstracted food into a very complex agricultural commodity derivative from its physical form. Second, the gap has blurred the nexus between the outcome of food systems and financial actors in manners that renders the opposing of financialization very challenging from a political perspective.

Isakson (2013) has also documented the growing trend of finance in food supply and established four main insights. According to the author, financialisation of agriculture and food has: (1) blurred the separation between food provisioning and finance; (2) reinforced the stance of food retailers (who are subject to capital finance) as the principal agro-food system actors; (3) increased the workload and exploitation of food workers while driving-down wages and; (4) made the livelihoods of small-scale farmers uncertain owing to growing agricultural market volatility.

In the second strand on food shortages, Berstein (2013) identifies and assesses some main elements that guide food sovereignty, notably: an attack on industrialized agriculture of the corporate sector as well as its consequences in the advent of globalization; advocacy and the peasant manner as the foundation of a socially just and sustainable food system and; an agenda to realize the goals. The author is skeptical about whether small producers practicing agro-ecological farming can feed the growing number of non-farmers in the world. Rosset (2009) has assessed the 'food sovereignty' proposal for tackling the crisis as well as the context of world food prices to conclude that agrofuels are not the fundamental cause of the crisis.

The position of Berstein is not broadly sustained by Mbunda (2013) who documents that the Tanzanian state and development partners like the World Bank are of the opinion that food shortages in the country (despite its relatively high potential for production) is the result of unsustainable peasant production. Hence there have been calls for de-peasantization to the benefit of commercial large scale farming as a panacea to the crisis. But the paper argues that de-peasantization should not be practiced in a country that is agrarian for the most part because the achievement of self-sufficiency in food is supposed to begin with the peasants. The paper recommends principles of food sovereignty in which the State plays a developmental role.

The third strand presents a synthesis of the first-two strands. In light of above debates, Van der Ploeg (2013) provides some synthesis by first stating that the concept of food sovereignty is a multidimensional and complex one to understand: both theoretically and empirically. The author, while identifying factors that could undermine its capacity, provides explanations as to why agriculture by peasants is robust and sustainable. By illustrating that there is seemingly no great difference between peasant agriculture and current food empires, the narrative provides a twodirectional nexus between the former and capital which helps to solidify the food sovereignty concept. Olanya (2012) has also postulated that this large-scale development in FLA in Africa is not a novel phenomenon and portrays the resurfacing of old practices in agribusiness which are conducted either via long-run leases or purchases.

In the fourth strand, we highlight some contrasting statistics. According to the UN (2010), a great chunk of FLA is meant for growing crops for energy and food security ambitions for the investing country and not so for domestic markets. This particular element in the acquisitions has very dire social, political and economic implications for countries in which food is already insecure. According to the narrative, many of the countries leasing out a substantial portion of their land are also those with the highest rate of undernourishment in the world. These include, inter alia: Ethiopia (46\%), Tanzania (35\%), Sudan (21\%), Mozambique (38\%), Madagascar (37\%), Kenya (32\%) and the Democratic Republic of Congo (76\%).

\section{Water and Energy Security}

In accordance with Bizikova et al. (2013), the elements of water security consists of: water safety; water access and water affordability to enable everybody lead a productive, healthy and clean life while protecting and enhancing the natural environment. Borrowing from the same authors, the 
elements of energy security entail: physical availability of the supplies, supply sufficiency to meet the demand at a particular price and continuity of supplies in energy, in relation to demand.

It is for the some of the above reasons that Saudi Arabia has decided to stop its food security program by 2016 because it is already almost depleting its water reserves (UN, 2010). In a broader perspective, the UN narrative sustains that a crucial interest in the current tendencies in FLA are factors of water and energy. Hence, water rights today are critical features in securing long-term investments in farming. While the UN (2010) narrative on these concerns have already been discussed above, it is important to highlight that security in the domestic level is becoming a source of serious conflicts in many regions. This thesis is validated by Olanya (2012) who has confirmed that in addition to the expansion of biofuel, the quest for FLA is motivated by the demand for more access to water. The underpinning logic is that because of climate change most industrialists believe acquiring farmland in proximity to a water reservoir is a guarantee for future agricultural productivity.

The most interesting account of the nexus between 'land grabbing' and water is provided by Woodhouse (2012). The author's study is motivated by the neglected role of access to water in FLA studies. The paper identifies the issues that emerge on implicit and explicit requirements in water for irrigation in projects of agriculture related to foreign investment transactions. The scope of the study is FLA in SSA where agricultural productivity is subjected to increasing rainfall constraints in savanna ecosystems that make-up about two-thirds of the region. An argument presented in the study is that, even in instances where the acquisition of land does not precise irrigation, location choice and/or type of crop show it is invariably an implicit constraint of the projects. It is argued that small scale producers in the neighborhood could benefit from private investment in water infrastructure, hence mitigating the risk that is inherent in a substantial portion of agriculture in Africa. Nonetheless, foreign investment could deplete other existing water uses which have led to the inclusion of provisions for water access priority in some land deals when there is scarcity. Based on empirical studies that are used to identify the channels, large FLA affects the availability of water for smaller-scale land users. Woodhouse (2012) have concluded that, although the incidence of resources on water could entail one of the principal effects of land deals, this is most likely to be opaque by the absence of transparency in the requirements of water for agricultural projects as well as the invisibility of existing agricultural water management at the local level to government planning agencies.

\section{Environmental Protection}

Another critical issue in the sustainability of FLA is environmental protection, which we discuss in two strands: in the first strand we briefly highlight some selected literature (Broad \& Cavanagh, 2013; UN, 2010; German et al., 2011) before laying particular emphasis on the issue of desertification in the second strand (Ingwe et al., 2010).

In the first strand, environmental concerns are growing in opposition to farming industrialization with preference for peasant-led local agriculture (Broad \& Cavanagh, 2013). This stance is supported by German et al. (2011) who sustain that in a large stream of recent publications related to environmental and social impacts, FLA has led to increasing issues from civil society on the subject of 'global land grabs'. In many of the countries hosting FLA, laws on herbicides, protection of biodiversity and water protection around farms are lacking. This creates substantial risks for other users of water, management of soil and the long-run sustainability of projects (UN, 2010). Local fisheries are not exempted from the plethora of risks discussed.

In the second strand, an interesting literature on desertification has been covered by Ingwe et al. (2010: 44-45). The narrative accounts that Africa has is a disproportionately substantial portion of dry land, with approximately $42 \%$ of the total area made-up of prolonged high evapo-transpiration and low precipitation. Almost all North African countries consist of dry sub-humid, semi-arid, arid and hyper-arid environments, which cannot support agriculture in the natural states. Some of the features extend to Western and Southern Africa that are characterized with substantial classes of dry land. Land degradation in the continent is also causing several other issues, especially its threatening nature to the livelihoods of residents in rural areas. It affects the catchment of rivers, forests and reduces ecosystems. A burgeoning population accompanied with increasing deforestation is also substantially increasing desertification (Asongu \& Jingwa, 2012; Asongu, 2014c). Ingwe et al. (2010) also establish that the concern of land degradation has been accelerated by climate change and other drought effects. 
This has led to a decrease in food production since the 1980s and the rural population has ignored the principles of sustainable management of scarce land resources.

\section{Socio-economic Protection}

Despite the urgent need for other sources of investment in Africa (Asongu, 2013b), FLAs in the continent have led to substantial socio-economic consequences (Thaler, 2013; Wouterse et al., 2011; Dessy et al., 2012; Starr, 2013; Lay \& Nolte, 2014; Burnett \& Murphy, 2013; German et al., 2011; Liu, 2013; UN, 2010; Wouterse et al., 2011; Ingwe et al., 2010;

Olanya, 2012). In the first strand, we discuss studies that are steadfast on the perilous role of FLA on poverty, labour conditions and social unrests. The second strand is focused on studies with a more balanced narrative.

According to Thaler (2013) in the first strand, corporations and foreign governments that purchase and lease large portions of arable land (especially in Africa) have led to riots, conflicts and protests from Madagascar to Mali. FLA besides displacing pastoralists and smallholder farmers has given way to the industrialization of farming for biofuel and export of crops to wealthier nations. This tendency deprives food production in local markets, especially in nations that are already experiencing substantial levels of food insecurity. A consequence could be that pastoralists and peasant farmers are forced to the wage economy, in which they have limited control over their subsistence and food sources.

Olanya (2012) finds that the expansion of investment in biofuel in the African continent has been accompanied with some support from the poor governments due to some perceived benefits in terms of support to poor farmers and sustainable energy development, reduction of greenhouse gas emissions and development of rural economies. However, the political economy of biofuels in development increases inequality for the poor because the crops and biofuel produced are destined primarily for foreign consumption: animal, energy and food purposes.

According to Wouterse et al. (2011), there is need for a proper institutional and legal environment so that contractual modalities in Africa can be tailored in a manner to balance the imperative to protect access by poor farmers to land and the need for investment security. The displacements of local farmers worsen already desperate socio-economic situations (Ingwe et al., 2010). As an extension, Liu (2013) has summarized the findings of case studies from the FAO on the impacts of FLA on host countries and communities to conclude that the disadvantages of such acquisitions often far outweigh the few benefits.

Specifically on labor rights, the UN (2010) has concluded that poor countries have few alternatives for safety and health standards at workplaces as many employers do not apply them in the sector of agriculture. Consequently, serious concerns emerge: for instance, human health concerns could arise in the handling of agricultural chemicals. This account is in line with the position of Ingwe et al. (2010) who have highlighted some of the problems associated with FLA, inter alia: employers are exploiting local workers with low wages and soaring food prices. These increasing food prices lead to social unrests for the most part.

The second strand consists of a stream of studies that present a more balanced narrative of the socio-economic effects of FLA. Lay \& Nolte (2014) have concluded that while they cannot invalidate the issues in the first strand, especially when employment creation and technology spillovers are not very likely to materialize, land-based investments in agriculture remain a very crucial topic for policy makers if well executed and monitored to lead to appealing spillovers. It is in this vein that Starr (2013) has called for a more nuanced analysis in processes of bargaining that underpin every land project/deal, so that potential policy measures attract investment without putting in jeopardy the lands and livelihoods of the vulnerable population. Along the same lines, Burnett \& Murphy (2013) have argued that trade is crucial for sustaining the livelihoods of small-scale producers who are already very active in the FLA movement. Still, according to their narrative, trade which is strategically important is not explored in discourses of FLA.

In assessing whether FLA represents a threat or an opportunity in Africa, Dessy et al. (2012) established that governments for the most part invest the proceeds of the deals to subsidize farming 
inputs that are used by local farmers, hence stimulating the creation of jobs in the local sector producing the inputs. The new job opportunities improve the pay of local workers to "wage employment' from a 'shifting status', therefore reducing farmland pressure. The model developed by Dessy et al. (2012) shows that welfare benefits to the local population critically depend on two sufficient and necessary conditions: (i) the host nation has land abundance, and (ii) the government should have a sufficiently high capacity to negotiate the projects/deals and be accountable to the local population in the negotiation of the said projects/deals.

The supporting role of domestic governments also merit some mention. German et al. (2011) have reviewed interviews and policy documents with government officials from various discussions with affected communities and customary leaders to provide a comparative analysis of institutional and legal frameworks as well as real practices linked to FLA in Mozambique, Ghana, Zambia \& Tanzania. They have concluded that in many cases, it is not a phenomenon of global 'land grab' that is greased by the private sector, but also a supply-driven process that involves an active role from domestic governments, often motivated by a strong faith in the mission of FLA in economic development.

The theoretical underpinnings above have also been substantiated by Thaler (2013) who has used FLA data from Land Matrix on conflict in Africa and found no significant correlation between FLA and social conflicts. However, it is important to note that the reliability of the dataset is not so accurate.

\section{Unbalanced Geopolitical Power}

Before engaging policy syndromes and implications, is it also relevant to briefly discuss the dimension on unbalanced geopolitical power which is another effect of FLA, though not substantially engaged in the literature. As far as we have reviewed, Ingwe et al. (2010) provides one of the most detailed accounts. According to the report, FLA projects in African countries are another means of increasing the geopolitical leverage of Western nations. The narrative holds that the continent has been belabored and beleaguered by legacies of devastating neocolonialism, unequal trade with Europeans, colonial rule and slavery, not forgetting structural adjustment programs that have brought untold miseries to the people, especially in SSA.

The study report presents a dialectical analysis of how this challenge is threatening sustainable development in the continent. It postulates that SSA's current shortcomings in maintaining its environmental, social and economic systems have been unfavorable for any equitable negotiations in FLA. According to the authors, Africa has been coerced into centuries of unequal nexuses with other regions operating in far developed capitalist systems that use a multitude of instruments (economic, political organizational, military...etc) to alienate and subdue the continent, especially in decision makings and determination of operating terms in globalizations. The points above make negotiations to be skewed towards Western interests, especially when it comes to issues about African land. In essence, the claim that Africa has much land for agriculture that is used to rationalize the scramble for land resources in the continent is unfounded and untrue. It is even morally repugnant because the continent is home to some of the most disadvantaged and poor communities that depend on the land for subsistence.

McMichael (2009) has also provided an interesting genealogy which accounts for the development of analysis in food regimes with respect to intellectual and historical trends during the past two decades. The interesting literature argues that the analysis of food regime underpins the foundational role of agriculture in political ecology/economy.

\section{POLICY SYNDROMES AND IMPLICATIONS}

According to Fosu (2013a), the term 'policy syndrome' is used to describe situations that are not favorable to growth, inter alia: 'suboptimal inter temporal resource allocations', 'state controls', 'state breakdown' and 'administered redistribution'. The author postulates that the syndromes have 
been responsible for the unappealing post-independence growth of the African continent. In the context of this chapter, 'policy syndromes' refer to situations and/circumstances that do not foster the equitable and sustainable development of FLA. The identified policy syndromes are the concerns discussed in Section 3 above. In light of the underlying syndromes, we discuss this section in six main strands: peasant rights, water \& energy issues, food security, environmental \& labor laws, transparency and, development \& employment opportunities.

In the first strand on peasant rights, Wouterse et al. (2011) have recommended the respect for land rights, including common and customary rights. Hence, those who are expropriated from their land should be rehabilitated and compensated to an equivalent livelihood. The UN (2010) in the same vein has recommended the provision of tools to all stakeholders. Such tools will critically help investors, local communities and development states in properly implementing the principles into domestic law and investment contracts. Such tools include, inter alia: best practice guides for land management and water efficiency, financing options and guides and, models of contracts in the investment domain. The authors of the report recommend that the asymmetry in law and rights between developed and African countries should be addressed. The basis of their recommendation is that developing countries for the most part provide greater protections to foreign investors and greater rights in treaties and contracts over incomplete or weak legal basis on environmental, economic and social concerns. Hence, like in the conclusion of agricultural contracts, foreign investors are favored in cases of voids.

The second narrative on water and energy security is broadly consistent with the first. FLA provides host countries with some minimum international standards. Hence, by accepting to lease contracts, host countries for the most part provide the water and energy means with which the companies involved in the FLA operate. Domestic laws or the investment contract should clearly articulate a periodic review of water rights and allocation for foreign investors and hence, what the investors are entitled to under international law. This procedure provides the investor with secured rights in event of a potential conflict with local communities in their needs for small industries and subsistence agriculture, small-scale farming and portable water. The element of prohibition without compensation found in international treaties should be fully incorporated. Whereas most treaties do not prohibit expropriation, they nonetheless require compensations to be executed when such does not take place. The periodicities of the FLA contracts (often between 50 to 99 years) raise important concerns for potential water and energy conflicts. Massive exploitation of water could lead to a fall in the water table of the local area when the issues become more acute. The UN (2010) report provides an excellent analysis of adoptable options in various scenarios.

The third strand discusses the policy syndrome of food insecurity. Wouterse et al. (2011) in this regard have provided a code of conduct. They have recommended sticking to national trade policies, especially when national food insecurity becomes an important concern (in the case of extreme drought for example), priorities should be given to domestic supplies. According to the authors, the right to export should not be given foreign investors in situations of extreme domestic food crisis. While such a policy is usually in breach of international laws on investment, such clauses should be included during the establishment of contracts and claims for compensation subject to this exceptions should also properly be negotiated to strike a delicate balance between investor motivation to keep producing in time of crisis and domestic consumption needs. Hence, a common agenda and recognition of shared needs are critical for food security.

As an extension of this strand, it is important to discuss technical and legal capacities that may be necessary (UN, 2010). Hence, receiving and investing countries should be more conscious of the legal ramifications and the potential incidence on the local population when it comes to access to water, food and land, as well as the consequences that could erupt during periods of national crisis or when national laws are changed. Accordingly, it is essential for host governments to factor expectations of potential land and water availability and value them into long-term purchases or leases negotiations. Technical support and short-term capacity is also critical in such projects. It is also essential to incorporate longer-run capacity building. Impact investigations should also be conducted on the costs, risks and benefits of land acquisition. While it is common for private investors to perform sustainability and feasibility studies for future land deals, receiving countries do not generally follow 
suit in carrying out the necessary examinations for potential domestic costs, risks and benefits. Such processes should incorporate inter alia: the provisions needed to safeguard legitimate objectives of public policy, there is a considerable flexibility to handling periods of domestic crisis and emergencies and, the imposition of performance requirements does not have a blanket prohibition.

The fourth policy syndrome on environmental and labour laws requires measures for environmental sustainability and initiatives that prevent the exploitation of local workers. Wouterse et al. (2011) have recommended that careful impact monitoring and examinations are needed to ensure sustainable and sound practices in agricultural production that prevent the depletion of soils, critical biodiversity loss, soaring emissions of greenhouse gases as well as considerable diversion of water from other environmental and human uses. Domestic governments should be aware of the fact that any changes to labor and environmental laws could lead to claims of contract breaches and compensation claims from foreign investors (UN, 2010). It is also important to note that today there is great unpredictability in the domain of international law, with two opposing views in the law case. One view sustains that a new law that is enacted for legitimate public needs could be construed as an indirect expropriation if there is a substantial economic effect on the FLA, while the other view is opposite. Domestic governments have been increasingly integrating the provisions that emphasize new measures on safety, environmental protection and public health; such initiatives are considered as indirect expropriation under international investment agreements. However, such agreements especially those in Asia and Africa where most land deals are occurring do not contain such changes. For the simple reason that it is unknown if such concerns are being addressed in international investment contracts, domestic governments have to consider all options seriously during the FLA.

The fifth policy syndrome is the absence of transparency in most FLA contracts. For transparency in negotiations to be established, owners of land at the local level must be involved in and informed of such land negotiations. Under such a scenario, informed, 'free and prior consent' are standards to be critically upheld. Substantial efforts are needed to uphold the rights of marginalized ethnic and indigenous groups. The information should also be made public to ease dissemination to civil society (and/or media) could a play a crucial role (Wouterse et al., 2011). In the same vein, the UN (2010) suggests that in order to improve participation and transparency, most stakeholders (especially local communities) should not be excluded from receiving information on agreed or potential deals or from participating in them. Achieving human rights to food, water, development, clean environments and work would substantially be contingent on people part-taking in the decisions that affect public policy. In this regard, full participation depends on transparency and the access of information in the process. Osabuohien (2014) has recently documented an interesting literature on how local institutions can be integrated into the FLA processes after concluding that these are overwhelmed by the State. Recommended measures include, inter alia: the formation of non-state workers to help in providing enlightenment, education and collaboration with local communities.

The sixth strand on employment and development opportunities is an extension of the fifth. In this regard, in order to improve the development and equity effects of such land contracts, requirements constraining the contribution of investors locally in economic terms should be included. Such clauses are known as 'performance requirements' in investment law. These include, amongst others: buying a certain proportion of local inputs, contributing an agreed part of local production to markets or local communities, awarding working contracts to the designated threshold of local labor and minimum degree of farming contract that provide training and technology transfer to the local community.

\section{CONCLUSIONS}

Large-scale agricultural land acquisitions have been covered substantially in recent literature. Despite the wealth of theoretical and empirical studies on this subject, there is no study that has reviewed existing literature in light of concerns over sustainable and equitable management. This chapter fills the gap by analyzing and synthesizing available literature to put some structure on existing knowledge. The chapter has a threefold contribution to the literature. First, it takes stock of what we know so far about the determinants of land grab. Second, it presents a picture of sustainable 
and equitable development of the foreign land acquisitions. Third, policy syndromes are examined and policy implications discussed. Based on the accounts, the issues are not about whether agricultural investments are needed, but on how they can be sustainably and equitably managed to make positive contributions to food security and domestic development.

\section{REFERENCES}

Abdioglu, N., Khurshed, A., \& Stathopoulos, K. (2013). Foreign institutional investment: Is governance quality at home important?, Journal of International Money and Finance, 32, 916-940.

AGRODEP (2013). Do Foreign Large-Scale Land Acquisitions decrease smallholder productivity in Africa?, AGRODEP Bulletin, Retrieved May 12, 2014, from

http://www.agrodep.org/sites/default/files/AGRODEP\%20Bulletin_Ed\%203_Vol\%204.pdf

Akpan, U. S., Isihak, S. R., \& Asongu, S. A. (2014). Determinants of Foreign Direct Investment in Fast-Growing Economies: A Study of BRICS and MINT, African Governance and Development Institute Working Paper, No. 14/002.

Aleksynska, M., \& Havrylchyk, O. (2013). FDI from the south: The role of institutional distance and natural resource, European Journal of Political Economy, 29, 38-53.

Amendolagine, V., Boly, A., Coniglio, N. D., Prota, F., \& Seric, A. (2013). FDI and Local Linkages in Developing Countries: Evidence from Sub-Saharan Africa, World Development, 50, 41-56.

Anyanwu, J. (2013). Determining the Correlated of Poverty for Inclusive Growth in Africa, African Development Bank Working Paper No. 181.

Anyanwu, J. (2012). Why Does Foreign Direct Investment Go Where It Goes?: New Evidence From African Countries, Annals of Economics and Finance, 13(2), 425-462.

Anyanwu, J., \& Augustine, D. (2013). Gender Equality in Employment in Africa: Empirical Analysis and Policy Implications, African Development Review, 25(4), 400-420.

Arezki, R., Deininger, K., \& Selod, H. (2011). What drives the global land rush?, IMF Working Paper No. $11 / 251$.

Asiedu, E. (2002). On the Determinants of Foreign Direct Investment to Developing Countries: Is Africa Different?, World Development, 30, 107-119.

Asiedu, E. (2006). Foreign Direct Investment in Africa: The Role of Natural Resources, Market Size, Government Policy, Institutions and Political Instability, The World Economy, 29, 63-77.

Asiedu, E., \& Lien, D. (2011). Democracy, foreign direct investment and natural resources, Journal of International Economics, 84, 99-111.

Asongu, S. A. (2012). Government quality determinants of stock market performance in African countries, Journal of African Business, 13(2), 183-199. 
Asongu, S. A. (2013a). Fighting consumer price inflation in Africa: what do dynamics in money, credit, efficiency and size tell us, Journal of Financial Economic Policy, 5(1), 39-60.

Asongu, S. A. (2013b). How Would Population Growth Affect Investment in the Future? Asymmetric Panel Causality Evidence for Africa, African Development Review, 25(1), 14-29.

Asongu, S. A. (2014a). Correcting Inflation with Financial Dynamic Fundamentals: Which Adjustments Matter in Africa?, Journal of African Business, 15(1), 64-73.

Asongu, S. A. (2014b). Globalization, (fighting) corruption and development: how are these phenomena linearly and nonlinearly related in wealth-effects?, Journal of Economic Studies, 41(3), 346-369.

Asongu, S. A. (2014c). Deforestation and Welfare: Evidence from Africa, International Journal of Green Economics: Forthcoming.

Asongu, S. A., \& Aminkeng, G. A. A. (2013). The economic consequences of China-Africa relations: debunking myths in the debate, Journal of Chinese Economic and Business Studies, 11(4), 261-277.

Asongu, S. A., \& Jingwa, B. A. (2012). Population growth and forest sustainability in Africa, International Journal of Green Economics, 6(2), 145-166.

Bartels, F. L., Alladina, S. N., \& Lederer, S. (2009). Foreign Direct Investment in Sub-Saharan Africa: Motivating Factors and Policy Issues, Journal of African Business, 10(2), 141-162.

Bartels, F. L. Napolitano, F., \& Tissi, N. E. (2014). FDI in Sub-Saharan Africa: A longitudinal perspective on location-specific factors (2003-2010), International Business Review, 23(3), 516-529.

Bernstein, H. (2013). Food Sovereignty: A skeptical view”, International Conference, Yale University, September 14-15, Retrieved May 12, 2014, from

http://www.tni.org/sites/www.tni.org/files/download/1_bernstein_2013.pdf.

Bizikova, L., Roy, D., Swanson, D., Venema, H. D., \& McCandless, M., (2013). “The Water-EnergyFood Security Nexus: Towards a practical planning and decision-support framework for landscape investment and risk management", International Institute for Sustainable Development, Retrieved May 12, 2014, from http://www.iisd.org/pdf/2013/wef_nexus_2013.pdf

Boyce, J. K., \& Ndikumana, L. (1998). Congo's odious debt: External borrowing and capital flight in Zair, Development and Change, 29,195-217.

Boyce, J. K., \& Ndikumana, L. (2001). Is Africa a Net Creditor? New Estimate of Capital Flight from Severely Indebted Sub-Saharan African Countries, 1970-1996, Journal of Development Studies, 38(2), 27-56.

Broad, R., \& Cavanagh, J. (2013). Gold for Export? ... or Water \& Food for Life?The Case of Gold Mining in El Salvador. International Conference, Yale University, September 14-15. Retrieved May 12, 2014, from http://www.tni.org/sites/www.tni.org/files/download/11 broad cavanagh 2013.pdf 
Buchanan, B. G., Le, Q. V., \& Rishi, M. (2012). Foreign direct investment and institutional quality: Some empirical evidence, International Review of Financial Analysis , 21, 81-89.

Burnett, K., \& Murphy, S., (2013). What Place for International Trade in Food Sovereignty? International Conference, Yale University, September 14-15, Retrieved May 12, 2014, from

http://www.tni.org/sites/www.tni.org/files/download/2_burnett_murphy_2013.pdf

Busse, M., \& Hefeker, C. (2007). Political risk, institutions and foreign direct investment, European Journal of Political Economy, 23(2), 397-415.

Büthe, T., \& Milner, H. V. (2008). The Politics of Foreign Direct Investment into Developing Countries: Increasing FDI through International Trade Agreements?, American Journal of Political Science, 52 (4), 741-762.

Clapp, J. (2013). Financialization, Distance and Global Food Politic, International Conference, Yale University, September 14-15. Retrieved May 12, 2014, from

http://www.tni.org/sites/www.tni.org/files/download/5_clapp_2013.pdf

Cleeve, E. (2012). Political and Institutional Impediments to Foreign Direct Investment Inflows to Sub-Saharan Africa, Thunderbird International Business Review , 54 (4), 469-477.

Collier, P. (2008). The Politics of Hunger How Illusion and Greed Fan the Food Crisis" Foreign Affairs, 87 (6), 6.

Cotula, L. (2013). The great African land grab? Agricultural investments and the global food system. Zed Books, London.

Cotula, L., Vermeulen, S., Leonard, R., Keeley, J. (2009). Land Grab or Development Opportunity?: Agricultural Investment and International Land Deals in Africa, London/ Rome

Cuervo-Cazurra, A. (2006). Who cares about corruption?, Journal of International Business Studies, $37,807-822$.

Darley, W. K. (2012). Increasing Sub-Saharan Africa's Share of Foreign Direct Investment: Public Policy Challenges, Strategies, and Implications, Journal of African Business, 13(1), 62-69.

De Janvry, A., \& Sadoulet, E. (2010). Agricultural Growth and Poverty Reduction: Additional Evidence, World Bank Research Observer, 25 (1), 1-20.

De Maria, W. (2010). Why is the president of Malawi angry? Towards an ethnography of corruption, Culture and Organization, 16(2), 145-162.

Dessy, S., Gohou, G., \& Vencatachellum, D. (2012). Land Acquisition in Africa: Threat or Opportunity for LocalPopulations?, African Development Bank Working Paper.

Economic Commission for Africa (2004). Land Tenure Systems and their Impacts on Food Security and Sustainable Development in Africa, ECA/SDD/05/09.

Fairbairn, M. (2013). 'Like gold with yield': Evolving intersections between farmland and finance, International Conference, Yale University, September 14-15. Retrieved May 12, 2014, from http://www.tni.org/sites/www.tni.org/files/download/6_fairbairn_2013.pdf 
Fosu, A. (2013a). Growth of African Economies: Productivity, Policy Syndromes and the Importance of Institutions, Journal of African Economies, 22(4), 523-551.

Fosu, A. (2013b). Institutions and African Economies: An Overview, Journal of African Economies, 22(4), 491-498.

Garoupa, N., \& Jellal, M. (2007). Further notes on information, corruption and optimal law enforcement, European Journal of Law and Economics, 23(1), 59-69.

Gastanaga, V. M., Nugent, J. B., \& Pashamova, B. (1998). Host country reforms and FDI inflows: How much difference do they make?, World Development, 26 (7), 1299-1314.

German, L., Schoneveld, G., Mwangi, E. (2011). Processes of Large-Scale Land Acquisition by Investors: Case Studies from Sub-Saharan Africa, Paper presented at the International Conference on Global Land Grabbing 6-8 April 2011.

Hajzler, C. (2014). Resource-based FDI and expropriation in developing economies, Journal of International Economics, 92 (1), 124-146.

Hathie, I., \& Yiyugsah, B. (2013). Energy and Food Security in Sub-Saharan Africa: Global Crisis, Local Impacts, Center for Democratic Development, Ghana.

Ingwe, R., Okoro, J., \& Ukwayi, J. K. (2010). The New Scramble for Africa: How Large-Scale Acquisition of Sub-Saharan Africa's Land by Multinational Corporations and Rich Countries Threaten Sustainable Development, Journal of Sustainable Development in Africa, 12(3), 2850 .

Isakson, R. (2013). Financialization and the Transformation of Agro-food Supply Chains: A Political Economy. International Conference, Yale University, September 14-15. Retrieved May 12, 2014, from

http://www.tni.org/sites/www.tni.org/files/download/9_isakson_2013.pdf

Jadhav, P. (2012). Determinants of Foreign Direct Investments in BRICS Economies: Analysis of Economic, Institutional and Political Factors. Procedia-Social and Behavioral Sciences , 37, $5-14$.

Jadhav, P., \& Katti, V. (2012). Institutional and Political Determinants of Foreign Direct Investment: Evidence From BRICS Economies, Poverty \& Public Policy, 4 (3), 49-57.

Kinda, T. (2010). Investment Climate and FDI in Developing Countries:Firm-Level Evidence, World Development, 38(4), 498-513.

Kolstad, I., \& Wiig, A. (2011). Better the Devil You Know? Chinese Foreign Direct Investment in Africa, Journal of African Business, 12(2), 31-50.

Lay, J., \& Nolte, K. (2014). Land grabs or simply investments? Determinants of foreign large scale land acquisitions in developing countries, GIGA German Institute of Global and Area Studies, Hamburg, Germany, and University of Göttingen.

Lipton, M. (2009). Land Reform in Developing Countries: Property Rights and property

Wrongs. New York: Routledge (or Taylor and Francis). 
Liu, P. (2013). Impacts of foreign agricultural investment on developing countries: evidence from case studies, Food and Agricultural Organization. Retrieved May 12, 2014, from file:///C:/Users/user/Downloads/Liu\%20(1).pdf

Loayza, N. V., \& Raddatz, C. (2010). The composition of growth matters for poverty alleviation, Journal of Development Economics, 93 (1), 137-51.

Jellal, M., \& Bouzahzah, M. (2013). Transparency and corruption: an optimal taxation policy, European Economics Letters, 2(2), 66-70.

Mbunda, R. (2013). The Developmental State and Food Sovereignty in Tanzania. International Conference, Yale University, September 14-15. Retrieved May 12, 2014, from http://www.tni.org/sites/www.tni.org/files/download/21_mbunda_2013.pdf

McMichael, P. (2009). A food regime genealogy, Journal of Peasant Studies, 36(1), 139-169.

Moosa, I. (2002). Foreign Direct Investment: Theory, Evidence and Practice. London: Palgrave.

Moosa, I. A., \& Cardak, B. A. (2006). The determinants of foreign direct investment: An extreme bounds analysis, Journal of Multinational Financial Management , 16, 199-211.

Neumayer, E., \& Spess, L. (2005). Do bilateral investment treaties increase foreign direct investment to developing countries?, World Development, 33 (10), 1567-1585.

Nguena, C. L. (2013a). Solutions Pratiques au déficit de financement des PME au Cameroun, ICBE Policy Brief, No. 32.

Nguena C. L. (2013b). Rethinking Pro-Growth Monetary Policy in Africa: Monetarist versus Keynesian Approach, Africa Economic Brief (AEB), 4.

Nyarko, Y. (2013). Sustaining High Economic Growth in Sub-Saharan Africa: Knowledge and the Structure of the Economy, Journal of African Economies, 22(suppl_1), -i101.

Okoth-Ogendo, H. W. (2008). The Last Colonial Question: An essay in the pathology of land administration systems in Africa. In: Helge Onsrud and Elena Busch (Ed.) Norwegian Land Tools Relevant to Africa Report, of a Workshop organized by the Norwegian Mapping and Cadastre Authority, 3-4 May 2007 (pp. 37-46). Oslo (Norway), Hpnefoss: Norwegian Mapping and Cadastre Authority.

Olanya, D. R. (2012). From Global Land Grabbing for Biofuels to Acquisitions of African Water for Commercial Agriculture, Current African Issues 50.

Osabuohien, E. S. (2014). Land-scale agricultural land investments and local institutions in Africa, Land Use Policy, 39,155-165.

Ranjan, V., \& Agrawal, G. (2011). FDI Inflow Determinants in BRIC countries: A Panel Data Analysis, International Business Research , 4 (4), 225-263.

Robertson, B., \& Pinstrup-Andersen, P. (2010). Global land acquisition: neo-colonialism or development opportunity?, Food Security, 2(3), 271-283.

Rogmans, T., \& Ebbers, H. (2013). The determinants of foreign direct investment in the Middle East North Africa region, International Journal of Emerging Markets , 8 (3), 240-257.

Rolfe, R. J., \& Woodward, D. P. (2004). Attracting foreign investment through privatization: the Zambian experience, Journal of African Business, 5(1), 5-27.

Rosset, P. (2009). Agrofuels, Food Sovereignty, and the Contemporary Food Crisis, Bulletin of Science Technology \& Society, 29, 189 -193. 
Sekkat, K., \& Veganzones-Varoudakis, M.-A. (2007). Openness, Investment Climate, and FDI in Developing Countries, Review of Development Economics , 11 (4), 607-620.

Starr, E. (2013). Food Sovereignty: A Critical Dialogue. International Conference, Yale University, September 14-15. Retrieved May 12, 2014, from

http://www.tni.org/sites/www.tni.org/files/download/78 starr 2013 0.pdf

Thaler, K. (2013). Large-Scale Land Acquisitions and Social Conflict in Africa, International Conference, Yale University, September 14-15. Retrieved May 12, 2014, from

http://www.tni.org/sites/www.tni.org/files/download/22_thaler_2013.pdf

Tsafack Nanfosso, R., \& Nguena, C. L. (2014a). Déterminants Microéconomiques du Déficit de Financement des PME au Cameroun, African Development Review : Forthcoming.

Tsafack Nanfosso, R., \& Nguena, C. L. (2014b). On the Sensitivity of Banking Activity Shocks: Evidence from the CEMAC Sub-region, Economics Bulletin, 34(1), 354-372.

Tsafack Nanfosso, R., \& Nguena, C. L. (2014c). Macroeconomic Factor and Dynamics of Financial Deepening: An empirical Investigation applied to the CEMAC Sub-region, African Journal of Economic Policy: Forthcoming.

Tuomi, K. (2011). The Role of the Investment Climate and Tax Incentives in the Foreign Direct Investment Decision: Evidence from South Africa, Journal of African Business, 12(1),133147.

United Nations (2010, January). Foreign land purchases for agriculture: what impact on sustainable development?, Sustainable Development and Innovation Briefs Issue No. 8.

Van der Ploeg, J. D. (2013). Peasant-driven agricultural growth and food sovereignty. International Conference, Yale University, September 14-15. Retrieved May 12, 2014, from

http://www.tni.org/sites/www.tni.org/files/download/8_van_der_ploeg_2013.pdf

Vijayakumar, N., Sridharan, P., \& Rao, K. C. (2010). Determinants of FDI in BRICS Countries: A panel analysis. International Journal of Business Science and Applied Management , 5 (3), 113.

Wei, S.-J. (2000). How Taxing is Corruption on International Investors? Review of Economics and Statistics, 82, 1-11.

Woodhouse, P. (2012). Foreign Agricultural Land Acquisition and the Visibility of Water Resource Impacts in Sub-Saharan Africa, Water Alternatives, 5(2), 208-222.

World Bank, (2007). Agriculture for Development: World Development Report 2008

Washington, D.C.: World Bank and Oxford University Press.

Wouterse, F., Deininger, K., Selod, H., Badiane, O., Swinnen, J., Von Braun, J., \& Zilberman, D. (2011). Foreign Direct Investment in Land in West Africa: The Status Quo, Lessons from Other Regions, Implications for Research, West \& Central Africa Office Thematic Research Note 1. 
Yin, J. Z., \& Vaschetto, S. (2011). China's Business Engagement in Africa, The Chinese Economy, 44 (2), 43-57.

\section{ADDITIONAL READINGS}

Aabo, E. \&Kring, T. (2012). The Political Economy of Large-Scale Agricultural Land Acquisitions: Implications for Food Security and Livelihoods/Employment Creation in Rural Mozambique, UNDP/RBA Working Paper, WP-2012-004.

George, T., Olayiwola, W.K., Adewole, M.A.\&Osabouhien, E.S. (2013). Effective service delivery of Nigeria's public primary education: Role of non-state actors.Journal of African Development, 15 (1), 221-245.

Grain, (2013). Collating and dispersing: Grain's strategies and methods.The Journal of Peasant Studies, 40 (3), 531-536.

Mungai, M. \& Omondi, P., (2014).Re-considering Large Scale Agricultural Investment as a New Paradigm for Mitigating Insecurity in Pastoral Rangelands: The Kenyan Case.In M.G. Berhe (Ed.),A Delicate Balance: Land Use, Minority Rights and Social Stability in the Horn of Africa(pp.245-281). Addis Ababa: Institute for Peace and Security Studies.

Mwangu, Alex R., (2014). Land-grabbing in Uganda: Are Pastoralists Second Class Citizens . In M.G. Berhe (Ed.), A Delicate Balance: Land Use, Minority Rights and Social Stability in the Horn of Africa (pp.192-223). Addis Ababa: Institute for Peace and Security Studies.

Osabuohien, E. and Efobi, U. (2011).Trade Outcomes in Africa's Regional Economic Communities and Institutional Quality: Some Policy Prescriptions.Economic Insights-Trends and Challenges, LXIII (4), 19-32.

Osabuohien, E.S. Ogundipe, A. \&Efobi, U.R. (2013). The land rush in Africa: Implications and institutional panacea.In E.E. Oku\&K.O. Asubonteng (Eds.), Harnessing land and water resources for improved food security and ecosystem services in Africa (pp. 92-106). Accra: UNU Institute for Natural Resources in Africa.

Timko, J.A. (2014). An analytical framework for assessing the impacts of jatrophacurcas on local livelihoods.In M. Bavinck, L.Pellegrini\& E. Mostertpp (Eds.), Conflicts over natural resources in the global south conceptual approaches (pp. 174-191). London: CRC Press.

\section{KEY TERMS AND DEFINITION}

Equitable development: this indicates the creation of opportunities for healthy vibrant communities so that the poor and local communities benefit from decisions, activities and systems that affect their neighborhoods.

Food security: means circumstances that are favorable to continuous availability of food.

Food sovereignty: refers to the right of countries to formulate policies that define and regulated their own food systems.

Foreign Direct Investment: the direct investment into business or production in a nation by a company or individual of a different country, either through the purchase of a corporation in the target nation or through the expansion of an operation or ongoing business in that nation. 
Foreign Land Acquisition (FLA): this refers to the leasing or buying of substantial pieces of land in less developing nations by individuals, governments and transnational companies.

Policy syndromes: these refer to situations and/circumstances that do not foster the equitable and sustainable development of FLA.

Sustainable development: means development that converges with the present without necessarily compromising the needs of future generations. 